\title{
Cytogenetics in Arctica islandica (Bivalvia, Arctidae): the Longest Lived Non-Colonial Metazoan
}

\author{
Daniel García-Souto ${ }^{1,2}$ and Juan J. Pasantes ${ }^{1, * \text { (D) }}$ \\ 1 Dpto. Bioquímica, Xenética e Inmunoloxía, Universidade de Vigo, E-36310 Vigo, Spain; \\ danielgarciasouto@gmail.com \\ 2 CIMUS Biomedical Research Institute, University of Santiago de Compostela, \\ E-15706 Santiago de Compostela, Spain \\ * Correspondence: pasantes@uvigo.es; Tel.: +34-986-812-577
}

Received: 29 May 2018; Accepted: 12 June 2018; Published: 13 June 2018

\begin{abstract}
Due to its extraordinary longevity and wide distribution, the ocean quahog Arctica islandica has become an important species model in both aging and environmental change research. Notwithstanding that, most genetic studies on ocean quahogs have been focused on fishery related, phylogeographic and phylogenetic aspects but nothing is known about their chromosomes. In this work, the chromosomes of the ocean quahog Arctica islandica were analysed by means of 4',6-diamidino-2-phenylindole (DAPI)/propidium iodide (PI) staining and fluorescent in situ hybridization (FISH) with rDNA, histone gene and telomeric probes. Whilst both $5 \mathrm{~S}$ rDNA and $45 \mathrm{~S}$ rDNA were clustered at single subcentromeric locations on the long arms of chromosome pairs 2 and 12, respectively, histone gene clusters located on the short arms of chromosome pairs 7, 10 and 17. As happens with most bivalves, the location of the vertebrate type telomeric sequence clusters was restricted to chromosome ends. The knowledge of the karyotype can facilitate the anchoring of genomic sequences to specific chromosome pairs in this species.
\end{abstract}

Keywords: ocean quahog; chromosome; fluorescent in situ hybridization; histone genes; ribosomal RNA genes; telomeric sequences

\section{Introduction}

The ocean quahog Arctica islandica (Linnaeus, 1767), the longest lived non-colonial animal, is the sole extant species of the family Arcticidae (Bivalvia) and inhabits continental shelves of the North Atlantic [1,2]. As this species has been commercially harvested for decades in North America and Iceland, the better studied aspects of its biology are those more directly related to fisheries and sustainable harvest [3]. The extraordinary longevity of ocean quahogs [1,4] together with its wide distribution have converted $A$. islandica in an important species model in both aging $[5,6]$ and environmental change research [7].

Only a few genetic studies have been performed in ocean quahogs. Mitochondrial cytochrome $b$ gene sequences [8] and random amplified polymorphic DNA [9] were used to evaluate genetic subdivision, demonstrating the existence of genetically distinct, non panmictic populations [9]. Transcriptome libraries were also generated in this species in order to study changes in the expression of oxidative stress related genes [10]. Molecular analysis of telomere dynamics [11] demonstrated that both telomerase activity and telomere lengths were independent of age and habitat in ocean quahogs, therefore suggesting that stable telomere maintenance might contribute to their longevity.

Furthermore, a sequencing project is in progress [12] for the nuclear genome of Arctica islandica whereas its mitochondrial genome was already sequenced [13]. As in many other bivalves, doubly uniparental inheritance was detected [14]. The mitochondrial genome sequence of the ocean 
quahog was used to infer phylogenetic relationships among bivalves $[13,15]$ and the phylogenetic trees recovered branched Arcticoidea either at the basis of Veneroidea [13] or as a sister group of Cyrenoidea and close to Veneroidea [15].

Molecular cytogenetic analyses have been published for a total of 32 species of eight families of heterodont bivalves, Cardiidae [16], Donacidae [17-20], Mactridae [21-24], Pharidae [25,26], Psammobidae [27], Veneridae [21,28-34], Solenidae [35] and Tellinidae [27,36]. Whilst in all of them diploid chromosome numbers were $2 n=38$ and vertebrate type hexamere repeats (TTAGGG) $n$ appeared just at telomeric locations, 45S rDNA, 5S rDNAs and $\mathrm{H} 3$ histone gene clusters showed differences in their distribution.

Despite the increased interest in the genetics of the ocean quahog, basic genetic data such as chromosome number or karyotype composition are unknown for this species. In this work, we determined the chromosome number and characterized the karyotype of the ocean quahog by staining its chromosomes with 4',6-diamidino-2-phenylindole (DAPI) and propidium iodide (PI) and fluorescent in situ hybridization (FISH) mapped telomeric sequences and 45S rDNA, $5 \mathrm{~S}$ rDNAs and H3 histone gene clusters to them.

\section{Materials and Methods}

Bivalve samples were provided by Thalassa Tradition [37]. Ocean quahog handling was conducted in accordance with guidelines and regulations established by the University of Vigo and the local government. The specimens were translated to Toralla Marine Science Station [38], identified according to shell morphology as Arctica islandica and maintained in running seawater at $14{ }^{\circ} \mathrm{C}$ for one week. Processing of the ocean quahogs was performed following procedures described for other bivalves $[39,40]$. After overnight exposure to colchicine, specimens were dissected and their sexes determined by microscopically analysing samples of their gonadic tissues. For each ocean quahog adductor muscles were preserved in absolute ethanol and gonadic and gill tissues were immersed in $50 \%$ (20 $\mathrm{min}$ ) and 25\% (20 min) sea water, fixed in ethanol:acetic acid (3:1, v:v, three times, $20 \mathrm{~min}$ each) and conserved at $-20{ }^{\circ} \mathrm{C}$.

DNA was extracted from adductor muscle tissue with the EZNA Mollusc DNA Kit (Omega Bio-Tek, Norcross, GA, USA) following manufacturer indications. DNA sequences were amplified in a GeneAmp PCR system 9700 (Applied Biosystems, Foster City, CA, USA) [20,23]. The pair of newly designed primers AIS-COIF: 5'TTGAGCAGGATTAATAGGAACT3' and AIS-COIR: 5'AAATGAACAAATAACACAGGATCT3' was used to amplify a $630 \mathrm{bp}$ long fragment corresponding to the mitochondrial cytochrome $\mathrm{c}$ oxidase subunit I (COI) gene. To confirm the morphological identification of the specimens, the amplified COI gene fragments were sequenced (Supplementary Figure S1).

A nick translation kit (Roche Applied Science, Penzberg, Germany) was used to label 28S rDNA probes with biotin-16-dUTP (Roche Applied Science) or digoxigenin-11-dUTP (10x DIG Labeling Mix, Roche Applied Science). PCR was employed to label H3 histone gene and $5 S$ rDNA probes with biotin-16-dUTP $(20 \mu \mathrm{M})$ or digoxigenin-11-dUTP $(5 \mu \mathrm{M})$ [20,23].

To prepare chromosome spreads, pieces of the fixed tissue were disaggregated in $60 \%$ acetic acid and the cell suspension spread onto preheated slides [41,42]. After staining with DAPI $(0.14 \mu \mathrm{g} / \mathrm{mL})$ and PI $(0.07 \mu \mathrm{g} / \mathrm{mL})$ for $8 \mathrm{~min}$, chromosome preparations were mounted with antifade (Vectashield, Vector) and photographed using a Nikon Eclipse-800 microscope equipped with a DS-Qi1Mc CCD camera (Nikon, Tokyo, Japan) controlled by the NIS-Elements software (Nikon) [20,23].

FISH mapping of H3 histone, 5S rRNA and 28S rRNA genes was carried out as described previously [43,44]. Karyotype analysis was performed in 10 specimens ( 5 females, 5 males). At least 10 metaphase plates per specimen were analysed. FISH mapping of the telomeric $\left(\mathrm{C}_{3} \mathrm{TA}_{2}\right)_{3}$ peptide nucleic acid (PNA) probe (Applied Biosystems) was also performed.

Karyotypes were constructed from 10 metaphase plates obtained from different specimens. Short and long arm lengths were measured for each chromosome. For each metaphase plate, 
relative lengths of each chromosome pair $(100 \times$ chromosome pair length/total length of all chromosome pairs) and centromeric indices of each chromosome $(100 \times$ short arm length/total chromosome length) were calculated. Mean relative lengths and centromeric indices were calculated from data obtained from 10 karyotypes. Chromosome nomenclature follows Levan et al. [45].

\section{Results}

The diploid chromosome number of Arctica islandica is $2 \mathrm{n}=38$ (Figure 1) and its karyotype is composed of 4 metacentric, 1 submeta/metacentric and 14 submetacentric chromosome pairs (Figure 1 , Table 1).
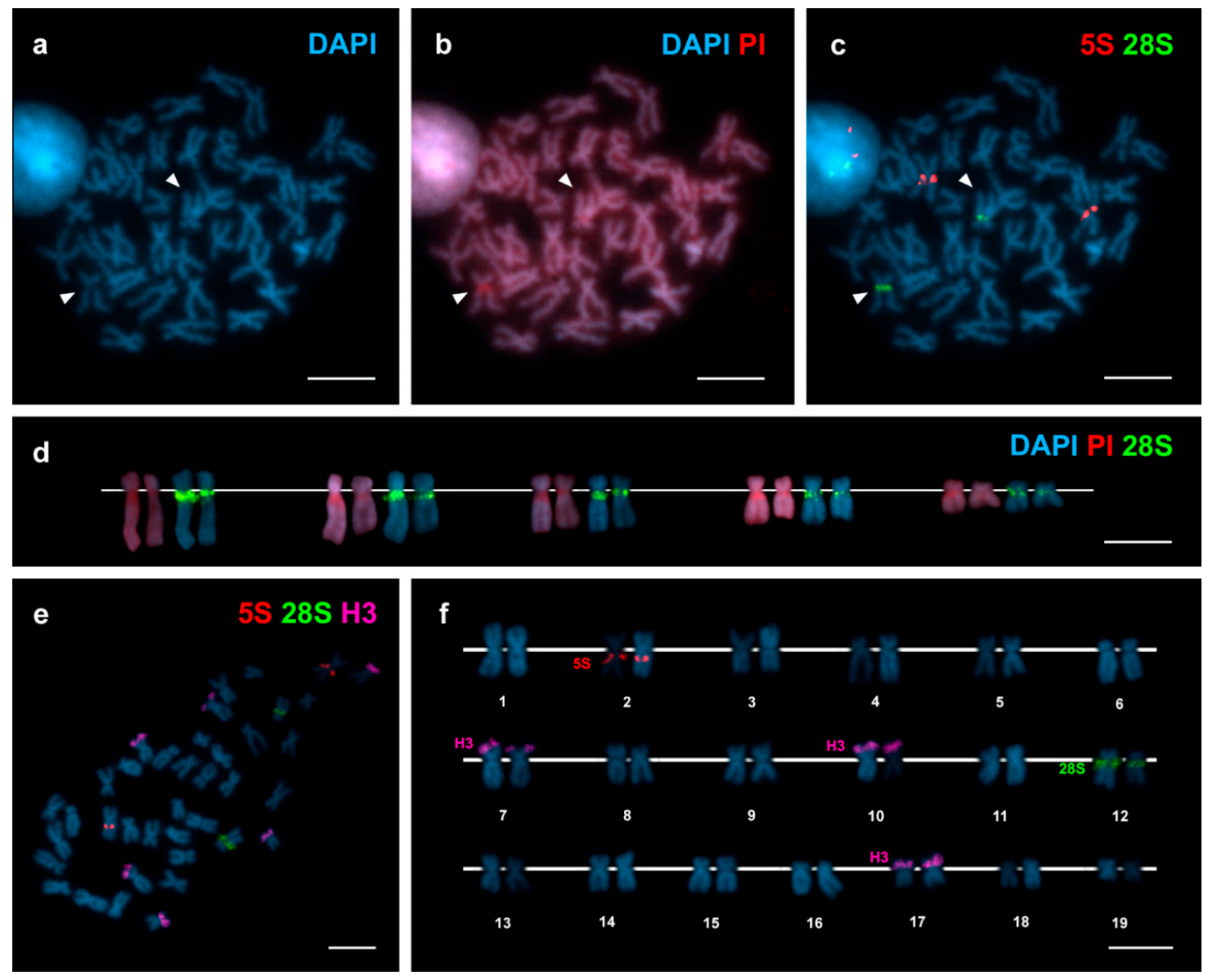

Figure 1. Chromosomal mapping of $28 \mathrm{~S} \mathrm{rDNA}, 5 \mathrm{~S}$ rDNA and $\mathrm{H} 3$ histone gene clusters in Arctica islandica. Mitotic metaphase plate stained with diamidino-2-phenylindole (DAPI) (a) and DAPI/ propidium iodide (PI) (b) shows DAPI negative regions (arrowheads) subcentromeric to the long arms of a single chromosome pair; these regions are red after DAPI/PI staining. Hybridization of the same metaphase plate with major and minor rDNA probes labelled differently (c) shows major rDNA signals (28S, green) coincident with the DAPI negative regions and minor rDNA signals (5S, red) subcentromeric to the long arms of a metacentric chromosome pair. As shown in (d), the sizes of the DAPI negative regions and the $28 \mathrm{~S}$ rDNA signals, differed between homologous chromosomes irrespective of their condensation degrees. Sequential fluorescent in situ hybridization (FISH) using major and minor rDNA and $\mathrm{H} 3$ histone gene probes on the same metaphase plate (e) and the corresponding karyotype (f), show H3 histone gene signals (H3, magenta) on the short arms of chromosome pairs 7, 10 and 17. Scale bars, $5 \mu \mathrm{m}$.

FISH analysis employing a telomeric $\left(\mathrm{C}_{3} \mathrm{TA}_{2}\right)_{3}$ PNA probe revealed terminal signals at both ends of every chromosome (Figure 2). The brightness of these telomeric signals showed a certain 
degree of heterogeneity being some of them brighter than other in homologous chromosomes and even at the chromosome ends of a single chromosome.
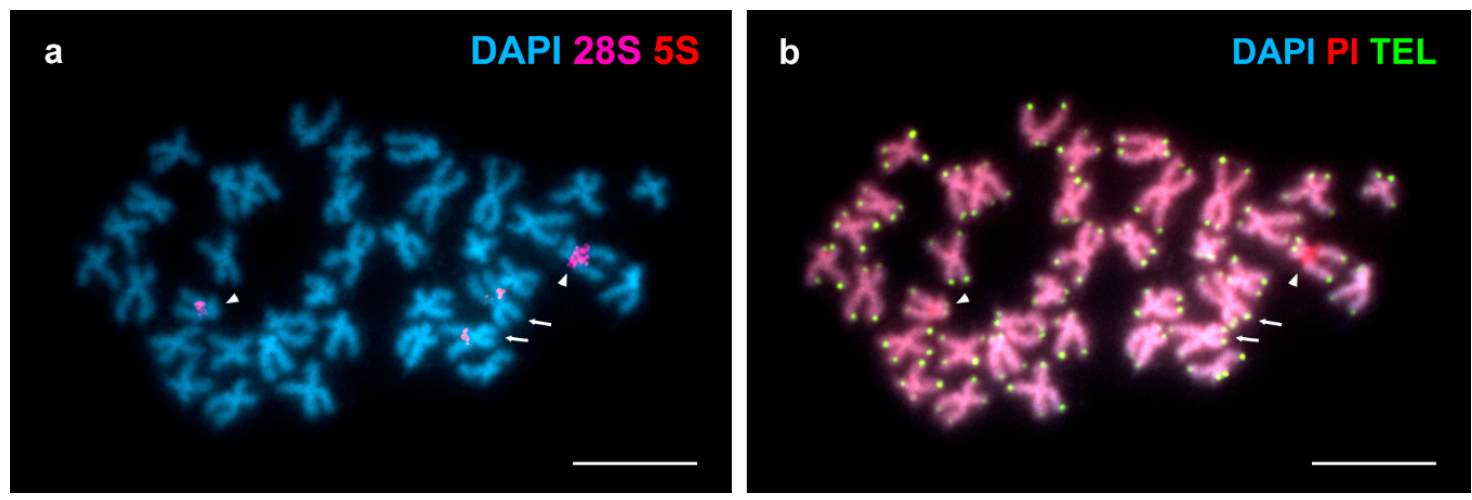

Figure 2. Mapping of telomeric sequences to Arctica islandica chromosomes. (a) DAPI stained metaphase plate hybridized with major (28S, magenta) and minor (5S, red) rDNA probes. (b) The same plate hybridized with a telomeric (TEL) $\left(\mathrm{C}_{3} \mathrm{TA}_{2}\right)_{3}$ PNA probe (TEL, green) and counterstained with DAPI/PI. Note that the short arms of chromosome pair 2 (arrows) display brighter telomeric signals than their long arms whereas the differences in brightness affect homologous chromosomes in pair 12 (arrowheads). Scale bars, $5 \mu \mathrm{m}$.

Table 1. Relative lengths and centromeric indices of Arctica islandica chromosomes.

\begin{tabular}{cccccc}
\hline \multirow{2}{*}{ Pair } & \multicolumn{2}{c}{ Relative Length } & \multicolumn{2}{c}{ Centromeric Index } & \multirow{2}{*}{ Type * } \\
\cline { 2 - 5 } & Mean & SE & Mean & SE & \\
\hline 1 & 6.86 & 0.17 & 41.35 & 0.45 & $\mathrm{~m}$ \\
2 & 6.12 & 0.10 & 36.34 & 0.74 & $\mathrm{sm}$ \\
3 & 6.05 & 0.10 & 42.20 & 0.67 & $\mathrm{~m}$ \\
4 & 5.97 & 0.13 & 30.39 & 4.01 & $\mathrm{sm}$ \\
5 & 5.80 & 0.12 & 32.31 & 3.01 & $\mathrm{sm}$ \\
6 & 5.49 & 0.08 & 29.51 & 1.97 & $\mathrm{sm}$ \\
7 & 5.41 & 0.12 & 33.94 & 1.72 & $\mathrm{sm}$ \\
8 & 5.38 & 0.09 & 34.37 & 1.74 & $\mathrm{sm}$ \\
9 & 5.37 & 0.08 & 34.61 & 2.23 & $\mathrm{sm}$ \\
10 & 5.22 & 0.11 & 41.76 & 0.91 & $\mathrm{~m}$ \\
11 & 5.21 & 0.04 & 35.47 & 1.34 & $\mathrm{sm}$ \\
12 & 5.15 & 0.11 & 30.07 & 1.11 & $\mathrm{sm}$ \\
13 & 5.08 & 0.06 & 33.39 & 1.68 & $\mathrm{sm}$ \\
14 & 4.94 & 0.07 & 32.09 & 1.32 & $\mathrm{sm}$ \\
15 & 4.92 & 0.10 & 29.50 & 1.33 & $\mathrm{sm}$ \\
16 & 4.79 & 0.06 & 34.37 & 1.69 & $\mathrm{sm}$ \\
17 & 4.58 & 0.05 & 37.10 & 1.81 & $\mathrm{sm} / \mathrm{m}$ \\
18 & 3.94 & 0.07 & 33.50 & 1.01 & $\mathrm{sm}$ \\
19 & 3.71 & 0.11 & 43.41 & 0.89 & $\mathrm{~m}$ \\
\hline
\end{tabular}

SE: Standard error; ${ }^{*} \mathrm{~m}$ : metacentric, sm: submetacentric.

\section{Discussion}

To date, chromosome numbers and karyotypes have been described for around 70 species of Heterodonta [23,24,32-34,36,46-50]. Although with exceptions as those in Cyrenidae, in which different levels of ploidy have been characterized [51] and Sphaeridae, whose chromosome numbers vary from 28 to 247 [52], most of these species presented diploid chromosome numbers of $2 n=38$ and karyotypes showing chromosome pairs with small length differences. As shown in Figure 1 and 
Table 1, the karyotype of Arctica islandica also displayed these characteristics. Furthermore, the absence of telocentric chromosome pairs in Arctica islandica is also shared by most heterodont species [26,36].

The occurrence of major rDNA signals in a DAPI negative, GC-rich region in one chromosome pair in A. islandica is coincident with the situation in most Heterodonta, in which 24 of the 32 species analysed showed a single location for these clusters $[16,17,19,20,22-35]$. As in ocean quahogs, nine of these 32 species displayed subcentromeric major rDNA clusters. Heteromorphisms in the size of the DAPI negative regions and the major rDNA FISH signals are also usual in Heterodonta $[28,30,32]$ and are likely the result of differences in the number of copies of the major rDNA repeats in homologous chromosomes.

Regarding $5 \mathrm{~S}$ rDNA, the occurrence of a single cluster in Arctica islandica is shared by another 14 of the 24 heterodont bivalve species previously analysed [16,20,23,24,26,30-34,36] but its subcentromeric location in Arctica islandica was previously only described in two other Heterodonta species, the mactra clam Mactra stultorum [23] and the tellin shell Macomangulus tenuis [36]. In contrast, subcentromeric 5S rDNA clusters were common in marine mussels [53].

In most of the 22 species of Heterodonta studied to date [20,23,24,30-34,36], H3 histone genes were clustered at one ( 15 species) or two ( 5 species) locations whereas the remaining two species, the venus clams Polititapes aureus [30] and Chamelea striatula [34] showed four clusters. The three H3 histone gene clusters detected in ocean quahogs thus represents an unusual situation; this could be related to their subtelomeric location that might facilitate their spreading to non-homologous chromosomes [34].

The detection of vertebrate type telomeric repeats exclusively at chromosome ends in Arctica islandica is coincident with results obtained in most bivalves; only the mussel Perumytilus purpuratus showed additional intercalary telomeric sequences in two chromosome pairs [41]. Concerning differences in brightness of the telomeric signals in Arctica islandica, as variability in telomere fluorescent intensity values within a single metaphase are due to heterogeneity of telomere lengths in mammals [54-57] probably the same applies to ocean quahogs. If this were the case, it is also possible that the critical element for cell viability in ocean quahogs were not mean telomeric lengths [11] but the lengths of the shortest telomeres [55-57]. Telomere quantitative FISH or other methods of telomere measurement [56] need to be applied to address the question.

In summary, as the knowledge of the karyotype of a species, a low-resolution map of its genome, is fundamental in any genome-mapping effort to solve the problems posed by the presence of repetitive sequences and large gene families, the results presented in this study could help anchoring genomic sequences obtained by next-generation sequencing technologies to specific chromosome pairs in the ocean quahog, an important species model in both aging and environmental change research.

Supplementary Materials: The following are available online at http://www.mdpi.com/2073-4425/9/6/299/ s1. Figure S1: Maximum likelihood tree based on mitochondrial COI gene sequences of Arctica islandica. References [58,59] are cited in the supplementary materials.

Author Contributions: D.G.-S. and J.J.P. conceived and designed the experiments; D.G.-S. and J.J.P. performed the experiments; D.G.-S. and J.J.P. analysed the data; J.J.P. contributed reagents/materials/analysis tools; D.G.-S. and J.J.P. wrote the paper.

Acknowledgments: D.G.-S. was partially supported by a FPU fellowship from “Ministerio de Educación, Cultura y Deporte" (Spain). This work was partly funded by a grant from Xunta de Galicia and Fondos FEDER: "Unha maneira de facer Europa" (Axudas do programa de consolidación e estruturación de unidades de investigacións competitivas do SUG: ED431C 2016-037).

Conflicts of Interest: The authors declare no conflict of interest. The founding sponsors had no role in the design of the study; in the collection, analyses, or interpretation of data; in the writing of the manuscript and in the decision to publish the results. 


\section{References}

1. Morton, B. The biology and functional morphology of Arctica islandica (Bivalvia: Arcticidae): A gerontophilic living fossil. Mar. Biol. Res. 2011, 7, 540-553. [CrossRef]

2. Ridgway, I.D.; Richardson, C.A. Arctica islandica: The longest lived non colonial animal known to science. Rev. Fish Biol. Fish. 2011, 21, 297-310. [CrossRef]

3. Hennen, D.R. How should we harvest an animal that can live for centuries? North Am. J. Fish. Manag. 2015, 35, 512-527. [CrossRef]

4. Abele, D.; Strahl, J.; Brey, T.; Philipp, E.E.R. Imperceptible senescence: Ageing in the ocean quahog Arctica islandica. Free Radic. Res. 2008, 42, 474-480. [CrossRef] [PubMed]

5. Philipp, E.E.R.; Abele, D. Masters of longevity: Lessons from long-lived bivalves-A mini-review. Gerontology 2010, 56, 55-65. [CrossRef] [PubMed]

6. Olsson, M.; Wapstra, E.; Friesen, C. Ectothermic telomeres: It's time they came in from the cold. Philos. Trans. R. Soc. B 2018, 373, 20160449. [CrossRef] [PubMed]

7. Schöne, B.R. Arctica islandica (Bivalvia): A unique paleoenvironmental archive of the northern North Atlantic Ocean. Glob. Planet. Change 2013, 111, 199-225. [CrossRef]

8. Dahlgren, T.G.; Weinberg, J.R.; Halanych, K.M. Phylogeography of the ocean quahog (Arctica islandica): Influences of paleoclimate on genetic diversity and species range. Mar. Biol. 2000, 137, 487-495. [CrossRef]

9. Holmes, S.P.; Witbaard, R.; van der Meer, J. Phenotypic and genotypic population differentiation in the bivalve mollusc Arctica islandica: Results from RAPD analysis. Mar. Ecol. Prog. Ser. 2003, 254, 163-176. [CrossRef]

10. Philipp, E.E.R.; Wessels, W.; Gruber, H.; Strahl, J.; Wagner, A.E.; Ernst, I.M.A.; Rimbach, G.; Kraemer, L.; Schreiber, S.; Abele, D.; et al. Gene expression and physiological changes of different populations of the long-lived bivalve Arctica islandica under low oxygen conditions. PLoS ONE 2012, 7, e44621. [CrossRef] [PubMed]

11. Gruber, H.; Schaible, R.; Ridgway, I.D.; Chowd, T.T.; Helde, C.; Philipp, E.E.R. Telomere-independent ageing in the longest-lived non-colonial animal, Arctica islandica. Exp. Gerontol. 2014, 51, 38-45. [CrossRef] [PubMed]

12. GOLD Genomes OnLine Database. Available online: https://gold.jgi.doe.gov/project?id=38667 (accessed on 12 February 2018).

13. Glöckner, G.; Heinze, I.; Platzer, M.; Held, C.; Abele, D. The mitochondrial genome of Arctica islandica; Phylogeny and variation. PLoS ONE 2013, 8, e82857. [CrossRef] [PubMed]

14. Dégletagne, C.; Abele, D.; Held, C. A distinct mitochondrial genome with DUI-like inheritance in the ocean quahog Arctica islandica. Mol. Biol. Evol. 2015, 33, 375-383. [CrossRef] [PubMed]

15. Fernández-Pérez, J.; Nantón, A.; Ruiz-Ruano, F.J.; Camacho, J.P.M.; Méndez, J. First complete female mitochondrial genome in four bivalve species genus Donax and their phylogenetic relationships within the Veneroida order. PLoS ONE 2017, 12, e0184464. [CrossRef] [PubMed]

16. Insua, A.; Freire, R.; Méndez, J. The $5 \mathrm{~S}$ rDNA of the bivalve Cerastoderma edule: Nucleotide sequence of the repeat unit and chromosomal location relative to 18-28S rDNA. Genet. Sel. Evol. 1999, 31, 509-518. [CrossRef]

17. Martínez, A.; Marinas, L.; González-Tizón, A.; Méndez, J. Cytogenetic characterization of Donax trunculus (Bivalvia: Donacidae) by means of karyotyping, fluorochrome banding and fluorescent in situ hybridization. J. Molluscan Stud. 2002, 68, 393-396. [CrossRef]

18. Plohl, M.; Prats, E.; Martínez-Lage, A.; González-Tizón, A.; Méndez, J.; Cornudella, L. Telomeric localization of the vertebrate-type hexamer repeat (TTAGGG)n in the wedgeshell clam Donax trunculus and other marine invertebrate genomes. J. Biol. Chem. 2002, 277, 19839-19846. [CrossRef] [PubMed]

19. Petrović, V.; Pérez-García, C.; Pasantes, J.J.; Šatović, E.; Prats, E.; Plohl, M. A GC-rich satellite DNA and karyology of the bivalve mollusk Donax trunculus: A dominance of GC-rich heterochromatin. Cytogenet. Genome Res. 2009, 124, 63-71. [CrossRef] [PubMed]

20. García-Souto, D.; Pérez-García, C.; Pasantes, J.J. Are pericentric inversions reorganizing wedge shell genomes? Genes 2017, 8, 370. [CrossRef] [PubMed]

21. Wang, Y.; Guo, X. Chromosomal mapping of the vertebrate telomeric sequence (TTAGGG)n in four bivalve molluscs by fluorescence in situ hybridization. J. Shellfish Res. 2001, 20, 1187-1190.

22. Wang, Y.; Guo, X. Chromosomal mapping of the major ribosomal RNA genes in the dwarf surfclam (Mulinia lateralis Say). J. Shellfish Res. 2008, 27, 307-311. [CrossRef] 
23. García-Souto, D.; Pérez-García, C.; Kendall, J.; Pasantes, J.J. Molecular cytogenetics in trough shells (Mactridae, Bivalvia): Divergent GC-rich heterochromatin content. Genes 2016, 7, 47. [CrossRef] [PubMed]

24. García-Souto, D.; Mravinac, B.; Šatović, E.; Plohl, M.; Morán, P.; Pasantes, J.J. Methylation profile of a satellite DNA constituting the intercalary $\mathrm{G}+\mathrm{C}$-rich heterochromatin of the cut trough shell Spisula subtruncata (Bivalvia, Mactridae). Sci. Rep. 2017, 7, 6930. [CrossRef] [PubMed]

25. Fernández-Tajes, J.; Martínez-Lage, A.; Freire, R.; Guerra, A.; Méndez, J.; González-Tizón, A.M. Genome sizes and karyotypes in the razor clams Ensis arcuatus (Jeffreys, 1985) and E. siliqua (Linnaeus, 1758). Cah. Biol. Mar. 2008, 49, 79-85. [CrossRef]

26. González-Tizón, A.; Rojo, V.; Vierna, J.; Jensen, K.T.; Egea, E.; Martínez-Lage, A. Cytogenetic characterisation of the razor shells Ensis directus (Conrad, 1843) and E. minor (Chenu, 1843) (Mollusca: Bivalvia). Helgol. Mar. Res. 2013, 67, 73-82. [CrossRef]

27. González-Tizón, A.M.; Martínez-Lage, A.; Rego, I.; Ausió, J.; Méndez, J. DNA content, karyotypes, and chromosomal location of $18 \mathrm{~S}-5.8 \mathrm{~S} 28 \mathrm{~S}{ }^{\circ} \mathrm{C}$ ribosomal loci in some species of bivalve molluscs from the pacific Canadian coast. Genome 2000, 43, 1065-1072. [CrossRef] [PubMed]

28. Hurtado, N.; Pasantes, J.J. Surface spreading of synaptonemal complexes in the clam Dosinia exoleta (Mollusca, Bivalvia). Chromosome Res. 2005, 13, 575-580. [CrossRef] [PubMed]

29. Wang, Y.; Guo, X. Chromosomal mapping of major ribosomal rRNA genes in the hard clam (Mercenaria mercenaria) using fluorescent hybridization. Mar. Biol. 2007, 150, 1183-1189. [CrossRef]

30. Carrilho, J.; Pérez-García, C.; Leitão, A.; Malheiro, I.; Pasantes, J.J. Cytogenetic characterization and mapping of rDNAs, core histone genes and telomeric sequences in Venerupis aurea and Tapes rhomboides (Bivalvia: Veneridae). Genetica 2011, 139, 823-830. [CrossRef] [PubMed]

31. Hurtado, N.; Pérez-García, C.; Morán, P.; Pasantes, J.J. Genetic and cytological evidence of hybridization between native Ruditapes decussatus and introduced Ruditapes philippinarum (Mollusca, Bivalvia, Veneridae) in NW Spain. Aquaculture 2011, 311, 123-128. [CrossRef]

32. Pérez-García, C.; Hurtado, N.S.; Morán, P.; Pasantes, J.J. Evolutionary dynamics of rDNA clusters in chromosomes of five clam species belonging to the family Veneridae (Mollusca, Bivalvia). BioMed Res. Int. 2014, 2014, 754012. [CrossRef] [PubMed]

33. García-Souto, D.; Pérez-García, C.; Morán, P.; Pasantes, J.J. Divergent evolutionary behavior of H3 histone gene and rDNA clusters in venerid clams. Mol. Cytogenet. 2015, 8, 40. [CrossRef] [PubMed]

34. García-Souto, D.; Qarkaxhija, V.; Pasantes, J.J. Resolving the taxonomic status of Chamelea gallina and C. striatula (Veneridae, Bivalvia): A combined molecular cytogenetic and phylogenetic approach. BioMed Res. Int. 2017, 2017, 7638790. [CrossRef] [PubMed]

35. Fernández-Tajes, J.; González-Tizón, A.; Martínez-Lage, A.; Méndez, J. Cytogenetics of the razor clam Solen marginatus (Mollusca. Bivalvia: Solenidae). Cytogenet. Genome Res. 2003, 101, 43-46. [CrossRef]

36. García-Souto, D.; Rios, G.; Pasantes, J.J. Karyotype differentiation in tellin shells (Bivalvia: Tellinidae). BMC Genet. 2017, 18, 66. [CrossRef] [PubMed]

37. Thalasa Tradition. Available online: http://www.thalassa-tradition.fr (accessed on 15 January 2018).

38. Estación de Ciencias Mariñas de Toralla (ECIMAT). Available online: https:/ / ecimat.uvigo.es/en/ (accessed on 15 January 2018).

39. Méndez, J.; Pasantes, J.J.; Martínez-Expósito, M.J. Banding pattern of mussel (Mytilus galloprovincialis) chromosomes induced by $2 \times$ SSC/Giemsa-stain treatment. Mar. Biol. 1990, 106, 375-377. [CrossRef]

40. Martínez-Expósito, M.J.; Pasantes, J.J.; Méndez, J. Proliferation kinetics of mussel (Mytilus galloprovincialis) gill cells. Mar. Biol. 1994, 120, 41-45. [CrossRef]

41. Pérez-García, C.; Cambeiro, J.M.; Morán, P.; Pasantes, J.J. Chromosomal mapping of rDNAs, core histone genes and telomeric sequences in Perumytilus purpuratus (Bivalvia: Mytilidae). J. Exp. Mar. Biol. Ecol. 2010, 395, 199-205. [CrossRef]

42. Pérez-García, C.; Guerra-Varela, J.; Morán, P.; Pasantes, J.J. Chromosomal mapping of rRNA genes, core histone genes and telomeric sequences in Brachidontes puniceus and Brachidontes rodriguezi (Bivalvia: Mytilidae). BMC Genet. 2010, 11, 109. [CrossRef] [PubMed]

43. Pérez-García, C.; Morán, P.; Pasantes, J.J. Cytogenetic characterization of the invasive mussel species Xenostrobus securis Lmk. (Bivalvia: Mytilidae). Genome 2011, 54, 771-778. [CrossRef] [PubMed] 
44. Pérez-García, C.; Morán, P.; Pasantes, J.J. Karyotypic diversification in Mytilus mussels (Bivalvia: Mytilidae) inferred from chromosomal mapping of rRNA and histone gene clusters. BMC Genet. 2014, 15, 84. [CrossRef] [PubMed]

45. Levan, A.; Fredga, K.; Sandberg, A.A. Nomenclature for centromeric position on chromosomes. Hereditas 1964, 52, 201-220. [CrossRef]

46. Nakamura, H.K. A review of molluscan cytogenetic information based on the CISMOCH-computerized system for molluscan chromosomes. Bivalvia, Polyplacophora and Cephalopoda. Venus (Jap. J. Malacol.) 1985, 44, 193-225.

47. Thiriot-Quiévreux, C. Advances in cytogenetics of aquatic organisms. In Genetics and evolution of aquatic organisms; Beaumont, A.R., Ed.; Chapman and Hall: London, UK, 1994; pp. 369-388. ISBN 9780412493706.

48. Thiriot-Quiévreux, C. Review of the literature on bivalve cytogenetics in the last ten years. Cah. Biol. Mar. 2002, 43, 17-26.

49. Leitão, A.; Chaves, R. Banding for chromosomal identification in bivalves: A 20-year history. In Aquaculture 1 Dynamic Biochemistry, Process Biotechnology and Molecular Biology 2; Russo, R., Ed.; Global Science Books: Ikenobe, Japan, 2008; pp. 44-49. Available online: http:/ / www.globalsciencebooks.info/Online/GSBOnline/ OnlineDBPBMB_2_SI1.html (accessed on 10 February 2018).

50. Arias-Pérez, A.; Insua, A.; Freire, R.; Méndez, J.; Fernández-Tajes, J.M. Genetic studies in commercially important species of Veneridae. In Clam Fisheries and Aquaculture; Da Costa González, F., Ed.; Nova Science Publishers: Hauppauge, NY, USA, 2013; pp. 73-105, ISBN 9781622575183.

51. Skuza, L.; Labecka, A.M.; Domagala, J. Cytogenetic and morphological characterization of Corbicula fluminalis (O. F. Müller, 1774) (Bivalvia: Veneroida: Corbiculidae): Taxonomic status assessment of a freshwater clam. Folia Biol. (Kraków) 2009, 57, 177-185. [CrossRef] [PubMed]

52. Petkevičiūtè, R.; Stunzènas, V.; Stanevičiūtè, G. Comments on species divergence in the genus Sphaerium (Bivalvia) and phylogenetic affinities of Sphaerium nucleus and S. corneum var. mamillanum based on karyotypes and sequences of 16S and ITS1 rDNA. PLOS ONE 2018, 13, e0191427.

53. García-Souto, D.; Sumner-Hempel, A.; Fervenza, S.; Pérez-García, C.; Torreiro, A.; González-Romero, R.; Eirín-López, J.M.; Morán, P.; Pasantes, J.J. Detection of invasive and cryptic species in marine mussels (Bivalvia, Mytilidae): A chromosomal perspective. J. Nat. Conserv. 2017, 39, 58-67. [CrossRef]

54. Lansdorp, P.M.; Verwoerd, N.P.; van de Rijke, F.M.; Dragowska, V.; Little, M.T.; Dirks, R.W.; Raap, A.K.; Tanke, H.J. Heterogeneity in telomere length of human chromosomes. Hum. Mol. Genet. 1996, 5, 685-691. [CrossRef] [PubMed]

55. Hemann, M.T.; Strong, M.A.; Hao, L.Y.; Greider, C.W. The shortest telomere, not average telomere length, is critical for cell viability and chromosome stability. Cell 2001, 107, 67-77. [CrossRef]

56. Vera, E.; Blasco, M.A. Beyond average: Potential for measurement of short telomeres. Aging (Albany NY) 2012, 4, 379-392. [CrossRef] [PubMed]

57. Ingles, E.D.; Deakin, J.E. Telomeres, species differences, and unusual telomeres in vertebrates: Presenting challenges and opportunities to understanding telomere dynamics. AIMS Genet. 2016, 3, 1-24. [CrossRef]

58. Kearse, M.; Moir, R.; Wilson, A.; Stones-Havas, S.; Cheung, M.; Sturrock, S.; Buxton, S.; Cooper, A.; Markowitz, S.; Duran, C.; et al. Basic: An integrated and extendable desktop software platform for the organization and analysis of sequence data. Bioinformatics 2012, 28, 1647-1649. [CrossRef] [PubMed]

59. Guindon, S.; Dufayard, J.F.; Lefort, V.; Anisimova, M.; Hordijk, W.; Gascuel, O. New algorithms and methods to estimate maximum-likelihood phylogenies: Assessing the performance of PhyML 3.0. Syst. Biol. 2010, 59, 307-321. [CrossRef] [PubMed]

(C) 2018 by the authors. Licensee MDPI, Basel, Switzerland. This article is an open access article distributed under the terms and conditions of the Creative Commons Attribution (CC BY) license (http:/ / creativecommons.org/licenses/by/4.0/). 